\title{
HAK INFORMASI ATAS BENCANA ALAM \\ DALAM KAJIAN HAK ASASI MANUSIA
}

\author{
Mariyadi; M. Taufik \\ Fakultas Hukum Universitas Islam Malang \\ Jl. MT. Haryono 193 Malang 65144, Telp 0341 - 551932, 551822, Fax.: 0341 - 552249 \\ Email: mariyadi@unisma.ac.id; emtaufik415152@gmail.com
}

\begin{abstract}
Cases of natural disasters in Indonesia classified as frequent. The following problem of the natural disaster is the victim rights. Indonesian bureaucrats often ignore the victim rights, so the victim condition that in concerns becomes even more alarming due to the neglect of the bureaucrats. In this case, disaster bureaucrats deserve to be positioned as human rights violator (disaster victims). This can be happened because of the information right on disaster is not informed faster and more accurate by bureaucrats.
\end{abstract}

Keywords: Human Rights, Disaster, Bureaucracy, Right of Information

\begin{abstract}
ABSTRAK
Kasus bencana alam di Indonesia termasuk yang tergolong sering. Problem yang mengikuti bencana alam adalah hak-hak korban. Para birokrat Indonesia seringkali mengabaikan hak korban, sehingga kondisi korban yang berada dalam keprihatinan menjadi lebih memprihatinkan lagi akibat pengabaian yang dilakukan para birokrat. Dalam ranah inilah, birokrat bencana layak diposisikan melakukan pelanggaran terhadap hak-hak asasi manusia (korban bencana). Hal ini bisa terjadi diantaranya disebabkan hak informasi atas bencana tidak cepat dan cermat disampaikan oleh birokrat.
\end{abstract}

Kata kunci: Hak Asasi Manusia, Bencana, Birokrasi, Hak atas Informasi.

\section{PENDAHULUAN}

Bencana alam seperti banjir dan tanah Dalam kasus bencana alam itu, kritik longsor sudah demikian sering terjadi. terhadap mental masyarakat Indonesia, Berdasarkan data sementara yang dihimpun khususnya mental kalangan aparat sudah PUSDALOPS Kepala Pusat Data Informasi berkali-kali dilakukan oleh pakar moral, dan Humas Badan Nasional Penanggulangan Bencana (BNPB) selama 2017, tercatat ada kejadian bencana sebanyak 654 bencana ${ }^{1}$. Bencana longsor di Ponorogo misalnya telah menjadi bencana yang mengakibatkan banyak orang kehilangan nyawa. agama, dan lainnya. Bahkan berkali-kali masyarakat Indonesia ini dilecehkan sebagai masyarakat yang mengidap krisis tanggung jawab, khususnya kalangan elit pejabatnya, namun mereka tidak banyak berreaksi. Meski sudah dikritik dengan cara menghujat

\footnotetext{
1 Michico, Nathania Riris, (2017, Februari 28), BNPB: 654 Bencana di Awal Tahun 2017, Potensi Banjir Meningkat. Diakses pada Mei 1, 2017. Dari Detik News: https://news.detik.com/berita/d-3433672/bnpb-654bencana-di-awal-tahun-2017-potensi-banjir-meningkat.
} 
sekalipun, tidak sedikit elit pejabat ini yang bersikap apatis, pura-pura tidak tahu, atau membiarkan kritik sebagai angin lalu. Mereka dituduh sebagai pejabat yang tidak serius, tidak tanggap atau tidak bertanggungjawab maksimal ketika bencana alam yang menimpa masyarakat terjadi.

Kelemahan kordinasi di antara petugas dan siapa saja yang secepatnya harus terjun ke lokasi bencana sudah menjadi bagian dari bencana yang menimpa masyarakat (korban) secara berkelanjutan. Dalam kondisi demikian, masyarakat kesulitan mengakses informasi yang bisa dipertanggungjawabkan, baik yang berkaitan dengan kondisinya sebagai korban maupun objektifitas bencana alam. Kelemahan ini menjadi cermin rentannya birokrasi bencana alam. ${ }^{2}$

Birokrasi pemerintahan di tingkat pelaksana atau pihak yang seharusnya bertanggungjawab secara langsung, sepertinya tidak pernah mau belajar dari pengalaman menangani bencana di berbagai daerah. Pilar-pilar birokrasinya tidak memiliki sikap atau kurang tanggap terhadap bencana yang terjadi. Masyarakat yang menjadi korban bencana alam tidak diperlakukan sebagai warga yang harus sesegera atau secepat mungkin dimanusiakan. ${ }^{3}$

\section{PEMBAHASAN}

\section{Birokrasi Bencana}

Salah satu catatan penting dalam setiap kali terjadi bencana alam adalah masalah birokrasi. Birokrasi bencana di Indonesia masih menjadi objek diskursus dimana-mana. Kritik pedas sering ditujukan pada birokrasi bencana. Sebagai contoh kasus, adalah penanganan bencana di Yogyakarta dan Jawa Tengah beberapa tahun lalu yang masih jauh dari memuaskan. Para pejabat terkait masih terlalu terpaku pada aturan birokrasi yang terlalu panjang dan berbelit-belit. Menurut Jeffrie Geovanie, bahwa semestinya untuk penanganan bencana di Yogyakarta dan sekitarnya, sudah bisa belajar dari penanganan bencana di Aceh. Rantai birokrasi bisa dipotong dan bantuan makanan dan kebutuhan mendesak, seperti tenda bisa cepat terdistribusi sehingga dapat mengurangi penderitaan para korban. ${ }^{4}$

Bagaimana bisa dalam kondisi bencana seperti di Yogyakarta, pejabat setempat masih mengharuskan yang menerima dana yaitu mereka yang mengambil ke posko seperti ketua RW atau Lurah. Apalagi ada juga yang mengharuskan warga membawa KTP mereka untuk mengambil bantuan. Hal ini jelas berbelit-belit karena penanganan bencana harus cepat. Seharusnya bantuan makanan cepat dikirim ke tempat yang sulit terjangkau

\footnotetext{
Walid, Waliduddin, (2014), Peta Bencana di Indonesia dari Waktu ke Waktu, Jakarta: Aliansi Media. Sidik, Ahmad. (2009), Negeri Bencana (Refleksi Perjalanan Musibah), Jakarta: Gerbang Pustaka. Suara Pembaharuan, 30 Mei 2006, diakses 1 Mei 2017.
} 
atau desa-desa yang masih terisolir (terpencil).

Dalam konsep ideal, seharusnya Pemerintah dan pejabat terkait segera membuat standar baku penanganan bencana. Dalam kasus demikian, Indonesia bisa belajar dari Jepang yang sudah sering mengalami bencana gempa bumi. Belajar dari hal ini, semestinya dapat dibentuk semacam garda nasional atau apa namanya, yang berfungsi sebagai tim penanganan bantuan secara cepat dan terkoordinasi atau mengutamakan perlindungan korban. Negara Jepang pernah mengalami bencana paling besar yaitu pada Maret 2011 terjadi gempa tektonik berkekuatan 8,9 skala richter yang diikuti tsunami setinggi 10 meter. Usai bencana berlalu, proses evakuasi korban dilakukan dengan cepat oleh Negara Jepang. Distribusi bantuan disalurkan dengan penuh tanggung jawab. Kemudian proses rekonstruksi berjalan sesuai jadwal. Disiplin yang tinggi mampu ditunjukkan dengan sikap yang menguatkan Jepang sebagai negara beradab. ${ }^{5}$

Dalam kasus di Yogya, penyaluran bantuan kepada korban gempa di Bantul, Daerah Istimewa Yogyakarta, dan Klaten, Jawa Tengah, terkesan lamban sehingga banyak warga belum menerima bantuan. Tim penyalur bantuan diminta menembus dan korban yang belum menerima bantuan bisa memperolehnya. Hal tersebut (pernah) dikemukakan Gubernur DI Yogyakarta Sultan Hamengku Buwono X dan Wakil Ketua DPRD Klaten yang juga Komandan SAR Daerah Klaten Anang Widayaka. Di pelosok dusun terpencil, seperti desa-desa di Kecamatan Dlingo dan Imogiri, bantuan yang diterima masih minim, kalau tidak dikatakan sangat terbatas. Bahkan, di tengah Kota Bantul di sepanjang jalan masih banyak anakanak dan orangtua yang langsung meminta bantuan kepada pemakai jalan karena bantuan belum memadai. keselamatan jiwa di atas segalanya, sehingga birokrasi yang lamban atau mempersulit haruslah dipangkas. ${ }^{6}$

Bencana di Yogyakarta memang meninggalkan pelajaran berharga, khususnya dalam hal penanganan korban. Misalnya penanganan korban bencana gempa bumi di Yogyakarta dan Jawa Tengah tergolong tidak beres alias amburadul (berjalan lamban dan tidak terarah), Terutama distribusi atau pembagian bantuan bahan pangan dan obatobatan belum juga lancar akibat lemahnya koordinasi birokrasi di lokasi bencana, padahal bantuan pangan dan obat-obatan sudah mengalir deras dari berbagai penjuru. Tapi bantuan tersebut lebih banyak

\footnotetext{
5 Muftisany, Hafidz. (2012, Oktober 10), Belajar Manajemen Penanganan Bencana dari Jepang. Diakses Mei 1, 2017. Dari News: http://nasional.republika.co.id/berita/nasional/umum/12/10/10/mbnmqa-belajar-manajemenpenanganan-bencana-dari-jepang.

6 Walid, Waliduddin. Op.Cit, Hlm. 11.
} 
menumpuk di tempat-tempat penampungan. Kondisi ini menandakan bahwa birokrasi bencana tidak berjalan dengan baik.

Saat menjadi Presiden Republik Indonesia, Susilo Bambang Yudhoyono sampai gusar menyikapi kondisi tersebut. Presiden sampai merasa perlu memerintahkan aparat di lapangan agar segera mendistribusikan bantuan makanan dan obat-obatan kepada para korban. Kondisi para korban, akibat tersendatnya distribusi bantuan makanan dan obat-obatan, kian memprihatinkan. Kelaparan tidak bisa dihindari karena persediaan bahan makanan nyaris habis. Sejumlah korban akhirnya jatuh sakit. ${ }^{7}$

Bencana tsunami di Pangadaraan pun demikian, ternyata pengalaman buruk dalam penanganan korban bencana alam pun terulang. Sebagian masyarakat yang menjadi korban bencana ini bukan hanya diserang berbagai bentuk penyakit, tetapi juga terancam kelaparan secara serius. (Kompas, 21 Mei 2006) Kondisi ini jelas patut menjadi tanggung gugat aparat yang diberi kewenangan menangani korban bencana alam, mengapa hingga sekarang aparat atau birokrat belum juga profesional dalam menjalankan tugas-tugasnya?

Menurut Programme Asociate Crisis Prevention and Rocovery unit lembaga PBB, UNDP yang juga Koordinator Pusat Data
BNPB, Ridwan Yunus Pusat data Badan Nasional Penanggulangan Bencana (BNPB) mencatat sebanyak 151.277 orang tewas akibat bencana alam yang melanda wilayah Indonesia dalam 13 tahun terakhir (1997 hingga 2009). Korban tewas itu akibat terjadinya sebanyak 6.632 kali bencana alam dalam 13 tahun (1997-2009) terakhir. ${ }^{8}$

Jumlah korban tewas dan jumlah bencana alam yang terjadi di Indonesia itu telah dicatat dalam Daftar Informasi Bencana Indonesia (DIBI) yang kini tengah disosialisasikan BNPB dan UNDP di provinsi-provinsi rawan bencana. Korban tewas paling banyak pada tahun 2004 saat terjadi gempa dan tsunami yang melanda Nanggroe Aceh Darussalam yang menyebabkan sebanyak 131.017 orang tewas. Selain gempa dan tsunami, selama 2004 terjadi sebanyak 895 kali bencana diseluruh wilayah Indonesia. Kemudian tahun 2006 tercatat sebanyak 7.495 orang meninggal akibat bencana alam dengan total kejadian bencana 815 kali, salah satunya gempa di Jogyakarta. Selanjutnya pada 1999 korban meninggal akibat bencana di Indonesia mencapai 3.492 orang dengan jumlah bencana terjadi 101 kali. Tahun 2005 korban meninggal dunia sebanyak 2.020 orang akibat 693 kali terjadi bencana, salah satunya gempa Nias. Korban meninggal dalam jumlah besar juga terjadi pada 2009

Sidik, Ahmad. Op.Cit, Hlm. 8

8 Suarakarya, 26 Pebruari 2010, dalam Suharmanto, Membedah Akar bencana, Fajar Ilmu, Surabaya, 2016, Hlm. 6. 
yang mencapai 1.807 orang, namun jumlah ini masih sementara karena penghitungan masih dilakukan BNPB. ${ }^{9}$

Tahun 2007 jumlah korban tewas dalam bencana sebanyak 942 orang, lalu tahun 2000 sebanyak 875 orang, 2005 sebanyak 634 orang, 1998 sebanyak 478 orang dan di tahun 2008470 orang meninggal dunia. Sementara tu dalam kurun waktu 1997-2009, bencana paling banyak terjadi pada tahun 2008 yang mencapai 1.302 kali. setelah 2008 bencana paling banyak kedua terjadi pada 2004 mencapai 895 kali, disusul tahun 2007 sebanyak 888 kali, tahun 2006 (851), tahun 2005 (693), tahun 2003 (532) dan tahun 1998 (497). Sedangkan, jumlah bencana paling sedikit terjadi pada tahun 1997 yakni hanya empat kali, disusul tahun 2000 sebanyak 82 kali dan tahun 1999 sebanyak 101 kali. Sementara itu, jumlah bencana melanda Indonesia selama 2009 masih dalam pendataan dan yang telah terdata sebanyak 498 kali. $^{10}$

Kasus bencana alam yang memprihatinkan tersebut sehausnya digunakan oleh setiap pemimpin daerah atau pejabat yang berwenang untuk membangun birokrasi yang sehat atau manajemen penanganan bencana alam yang profesional. Kelemahan birokrasi telah mengakibatkan masyarakat yang terkena bencana alam menghadapi kondisi yang lebih memprihatinkan, mereka bisa terpuruk dalam beragam ketidakberdayaan.

\section{Tanggungjawab Negara}

Bencana alam merupakan ujian terhadap tanggung jawab negara. Bencana alam yang sering terjadi memang berdampak terhadap kehidupan masyarakat, khususnya yang menjadi korban bencana alam, akan tetapi dampak keprihatinan yang menimpa korban ini seringkali diikuti problem berat lainnya, yang bukan berasal dari alam, tetapi dari diri manusia. Akar masalah dari diri manusia ini berupa kesalahan manusia atau seseorang dan sejumlah orang yang dipercaya menjadi birokrat dalam penanganan bencana alam.

Sosiolog kenamaan Gunnar Myrdal yang pernah melakukan penelitian terhadap kondisi borokrasi di negara-negara kawasan Asia, menunjukkan temuannya, bahwa secara umum birokratisasinya dikendalikan oleh manusia-manusia (birokrat) yang bermental lamban kerja, sehingga mengakibatkan lahirnya konstruksi negara yang beridentitas "negara lembek" (soft state). ${ }^{11}$

Dalam "negara lembek" itu, birokrasi negara menjadi lamban melayani atau menangani kepentingan publik. Apa yang sedang dibutuhkan oleh masyarakat yang bersifat segera, secepatnya, atau darurat, tidak dijadikan sebagai proyek kinerja

\footnotetext{
9 Ibid.

${ }^{10}$ Ibid.

11 Sidik, Ahmad. Op.Cit, Hlm. 13.
} 
istimewanya. Unsur birokrasi ini tidak cerdas membaca realitas kepentingan publik yang seharusnya diselesaikan, karena selain kapabilitasnya rendah, juga otaknya sebatas memikirkan cara-cara mengambil keuntungan melalui jalan pintas dari birokrasi yang dilaksanakannya. ${ }^{12}$

Dalam kasus Indonesia, kenyataan menunjukkan, birokrasi merupakan salah satu sarang utama praktik korupsi, kolusi, dan nepotisme $(\mathrm{KKN})$ di negeri ini. Di tingkat opini publik pun menyatakan demikian. Tidak heran, jika berbagai penilaian negatif seringkali dialamatkan kepada birokrasi. Misalnya, birokrasi dikatakan suka melakukan pungli (pungutan liar) dan gemar melakukan suap-menyuap, sehingga mengakibatkan ekonomi biaya tinggi (high cost economy) bagi masyarakat pengguna jasa birokrasi. Para pejabat di dalamnya pun banyak sekali yang hobi korupsi, mempermainkan proyek pembangunan, "sunat" sana "sunat" sini, dan berbagai bentuk penyelewengan lainnya. Birokrasi kerap pula dituding tidak profesional, suka menundanunda pekerjaan, lamban, kaku, berbelit-belit, tidak responsif, kurang bertanggung jawab, dan tidak produktif. ${ }^{13}$

Birokrat di negeri seperti itu tidak sedikit yang mentalitasnya kleptokrat atau obsesi dan aksinya lebih berupa trik-trik menunggangi birokrasi untuk mengambil keuntungan berlipat. Keuntungan ini tidak sulit diperolehnya, karena mata, telinga, mulut publik berusaha dijauhkan dari informasi yang bersifat objektif. Dalam urusan pelayanan publik, misalnya, sebagai tugas dan tanggung jawab utama birokrasi, penelitian yang dilakukan oleh Pusat Studi Kependudukan dan Kebijakan (PSKK) Universitas Gadjah Mada (Agus, 2002) di tiga provinsi yakni Yogyakarta, Sumatera Barat, dan Sulawesi Selatan menunjukkan bahwa kinerja birokrasi masih sangat buruk. Dikatakan, birokrasi belum mampu menyelenggarakan pelayanan publik yang efisien, adil, responsif, dan akuntabel. Dari seluruh indikator yang digunakan sebagai alat ukur, ditemukan kenyataan betapa kinerja birokrasi masih sangat jauh dari yang diharapkan. Menarik dikemukakan, bahwa salah satu penyebab buruk dan rendahnya kinerja birokrasi, menurut penelitian PSKK tersebut, adalah tidak adanya etika pelayanan yang kuat dan bisa digunakan oleh para pejabat birokrasi untuk menyelenggarakan pelayanan publik yang baik. ${ }^{14}$

Dalam birokrasi seperti itu, sudah lama kita kenal birokrat yang menyandang identitas sebagai "pegawai bepangkat kopral, tetapi penghasilan tetapnya berklas jenderal". Mereka ini sangat pandai membaca peluang

\footnotetext{
12 Hariyono, Didik. (2015), Birokrasi Bencana di Indonesia. Jakarta: Xpress Indonessia.

13 Aziz, Abdul dalam Waliduddin Walid, Op.Cit, Hlm. 12.

14 Ibid, Hlm. 13-14.
} 
yang bisa dieksploitasi, dipolitisasi, atau "dibahasakan" sebagai sumber pendapatan yang menguntungkan.

Zunaidi Abdullah menyatakan, bahwa beberapa kali gempa dan bencana alam terjadi di Indonesia. Ini mestinya membuat pemerintah Indonesia semakin cerdas dan cepat dalam menangani musibah besar tersebut. Tetapi, fakta di lapangan menunjukkan lain. Para birokrat selalu suka berbelit dan bekelit ketika musibah datang. Proses penanganan itu sepertinya sengaja dibuat lamban dan rumit. Hal itu sangat dimungkinkan karena adanya permainan yang bisa menguntungkan kelompok dan orang tertentu. Hal ini bisa dilihat dari dua sisi. Pertama dari nilai ekonomis dan kedua dari sisi politis ketika musibah gempa dan bencana alam datang. ${ }^{15}$

Dari sisi ekonomis, bantuan yang akan dialirkan sangat menggoda untuk disunat. Akibatnya, bantuan yang tiba ke masyarakat sudah melalui saringan yang bernama kolusi, korupsi, dan nepotisme yang rumit dan berbelit, yang dilakukan pejabat terkait. Jadi, tidak heran bantuan yang mengucur ke masyarakat sangat lamban dan kurang dari yang diharapkan. Dari sisi politis, bantuan untuk gempa memiliki nilai yang bisa mendatangkan simpati dari masyarakat. Akibatnya, kalangan birokrat saling berebut pengaruh untuk menyalurkan dana bantuan.
Efek perebutan pengaruh itu membuat penyaluran dana bantuan terkatung-katung.

Dalam kondisi seperti itu, sulit (kalau tidak dibilang mustahil), ada kepentingan masyarakat yang sedang menghadapi kesulitan, penderitaan, dan keprihatinan, yang dijadikan sebagai objek utama kinerjanya. Indikasinya, dalam setiap kasus bencana alam, hampir menjadi cerita rutin kalau mereka yang sedang menjadi korban bencana alam adalah manusia-manusia yang sedang berbalut penderitaan berlapis akibat "sudah jatuh tertimpa tangga pula".

Masyarakat korban bencana itu dibiarkan menempati kantong-kantong ketidakberdayaan dan ketidakmanusiawian oleh briokrat. Faktanya, seiring dengan derita akibat bencana alam ini, mereka juga menjadi korban bencana struktural, yang tentu saja mngakibatkan penderitaan yang lebih besar, karena dari bencana struktural ini, hak-hak yang semestinya diterima, justru dihambat, dirampas, atau dialihkan peruntukannya.

"Kejahatan" atau bencana struktural merupakan deskripsi dari bencana lapis kedua yang diterima oleh masyarakat korban bencana. Masyarakat yang sedang menderita ini harus menanggung beban dari janji-jaji palsu birokrat atau elemen struktural yang membutakan mata hatinya, menghilangkan jiwa profesionalitas, dan mematikan komitmen humanitasnya.

\footnotetext{
15 Ibid, Hlm. 15.
} 
Mereka yang kehabisan cadangan pangan di lokasi bencana dan sudah lama menunggu kebijakan pemerintah yang bersifat populis dan tanggap panggilan kemaslahatan publik akhirnya harus menanggung derita kelaparan hingga berhari-hari akibat ulah birokrat yang kinerjanya lamban dan cari-cari untung. Mental birokrat kita masih saja mengikuti prinsip "kalau bisa dibuat sulit kenapa harus dibuat mudah", dan bukan "kalau bisa dibuat mudah, kenapa harus dibuat sulit".

Masyarakat yang sedang jadi korban bencana alam yang kemudian dikorbankan secara struktural-birokratis itulah yang disebut oleh agama sebagai orang-orang yang sedang tidak berdaya, sebagai manusiamanusia yang dibuat lemah, dimiskinkan, dibuat menderita, atau dikorbankan oleh sistem, sehingga membuatnya tidak berdaya. Penderitaannya gagal dientas secara tuntas oleh pemerintah, karena pemerintah hanya berjanji atau sekedar menunjukkan jiwa karitasnya, bukan jiwa pengabdiannya.

Bangsa ini sudah berkali-kali dibuat terhenyak atau dibuat prihatin dengan bencana kelaparan yang mengakibatkan sebagian orang meninggal dunia di daerahdaerah pedalaman, yang kasus keprihatinan ini berangkat dari lambanya kinerja birokrat Indonesia. Bagaimana mungkin di negeri yang dikenal sebagai lumbung padi atau lahan paling subur di dunia ini, sampai ada rakyat yang meninggal dunia akibat kelaparan. Namun fakta sudah membuktikan, bahwa sudah kesekian kali, ada anak bangsa yang mati mengenaskan yang secara tidak langsung diakibatkan bencana struktural. ${ }^{16}$

Ada bahan refleksi. Kasus yang pernah menimpa sebagian masyarakat pedalaman Korea Utara layak dijadikan pelajaran, bahwa akibat kelaparan yang menimpanya, mereka memilih jadi kanibal. Pilihan ini terpaksa dilakukan sebagai wujud kritik radikalnya terhadap kinerja birokrasi yang menghambat penyaluran bantuan kemanusiaan kepadanya. Birokrat-birokrat ini sibuk menjarah hak-hak masyarakat pedalaman atau menghambat penyalurannya supaya konsumsi masyarakat tidak berlebihan, sehingga birokrat bisa mengambil keuntungan.

Meski kasus tersebut belum sampai terjadi di Indonesia, tetapi cerita memilukan sudah seringkali keluar, bahwa masyarakat korban bencana alam dan daerah pedalaman sudah sering menjadi korban bencana struktural yang dilakukan oleh birokrat bermental korup, kleptomania, dan tidak tanggap kebutuhan darurat. Adapun yang dianggapnya darurat adalah kebutuhan pribadi, keluarga, dan kroni-kroninya, sementara kebutuhan riil masyarakat dianggap sebagai "proyek" yang harus dijadikan obyek pemerasan terusmenerus.

\footnotetext{
16 Sidik, Ahmad. Op.Cit, Hlm. 13.
} 
Di tengah kondisi masyarakat yang sudah semakin cerdas atas hak-haknya ini, suatu kesalahan besar jika birokrasi dijalankan oleh mesin-mesin (manusia-manusia) yang sudah seharusnya "pensiun" atau manusia yang seharusnya tidak perlu menjadi pilar birokrasi. Layanan publik yang masih tetap mempercayakan pada birokrat, merupakan tantangan yang harus dijawab oleh birokrat dengan prinsip akuntabilitas moral dan kinerja profesionalitas.

\section{Hak Informasi dalam Perspektif HAM}

Dalam menghadapi banyaknya atau seringnya terjadi bencana alam di Indonesia, salah satu aspek penting harus disampaikan (diinformasikan) kepada masyarakat adalah hak informasi, sehingga masyarakat bisa dicegah atau diselamatkan dari kemungkinan ditimpa bencana alam atau ditimpa problem komplikatif akibat terjadinya bencana alam. Problem komplikatif menjadi problem yang secara fundamental menyengsarakan kehidupan masyarakat. Akibatnya, bencana alamnya berlanjut menjadi bencana yang berhubungan dengan kelemahan atau kesalahan kinerja aparat. ${ }^{17}$

Dalam Universal Declaration of Human Rights (UDHR) atau dikenal dengan DUHAM (Deklarasi Universal Hak Asasi Manusia) disebutkan, bahwa pengingkaran dan pelecehan (disregard and contempt) terhadap hak manusia telah menyebabkan terjadinya tindakan-tindakan biadab yang telah menimbulkan kemarahan kesadaran umat manusia, dan bahwa munculnya dunia di mana umat manusia dapat menikmati kebebasan untuk berbicara dan menganut kepercayaan (freedom of speech and belief) dan kebebasan dari ketakutan dan kekurangan (kemiskinan) telah diproklamasikan sebagai aspirasi bagi semua orang.

Dalam UDHR tersebut sudah jelas disebutkan tentang kewajiban manusia dan negara untuk memperlakukan manusia secara beradab, dan bukan perlakuan-perlakuan yang bercorak ketidak-adaban. Perilaku tidak beradab atau pelecehan terhadap harkat kemanusiaan, dapat melahirkan ketidakadaban baru atau mengundang lahirnya tindakan-tindakan anarkis dan tidak beradab pula.

Sayangnya, meski sudah ada garis norma yang mengajak setiap manusia dan negara berperilaku beradab, memanusiakan manusia, atau mencegah berbagai perbuatan buruk yang menyakiti sesama, ternyata manusia tetap saja belum ada tanda-tanda akan menghentikan perbuatan tidak terpujinya. Pelanggaran hak asasi manusia tetap saja mengiringi langkah manusia dari waktu ke waktu. Pelanggaran hak asasi ini salah

\footnotetext{
17 Toha, Abdillah. Pilkada Berbasis Kemasyarakatan, Makalah disampaikan dalam diskusi di Lembaga Kajian Ilmu Pengetahuan, Teknologi, dan Islam (LPITI) yang bekerjasama dengan Pusat Kajian HAM Fakultas Hukum Unisma Malang, tanggal 15 Agustus 2009, Hlm. 2-3.
} 
satunya bisa disebabkan kelemahan produk hukum yang tidak sejiwa dengan konstitusi. Karena tidak sejiwa dengan konstitusi ini, maka akibatnya memberikan peluang bagi terjadinya pelanggaran HAM. ${ }^{18}$

Dalam Artikel 5 UDHR dipertegas, bahwa Tidak seorang pun boleh disiksa (torture) atau mendapat hukuman dan perlakuan yang kejam, tidak berperikemanusiaan dan merendahkan martabat manusia (cruel, inhuman or degrading treatment). Dalam pasal 1 angka (1) UU Nomor 39 Tahun 1999 tentang Hak Asasi Manusia menyebutkan, bahwa HAM itu seperangkat hak yang melekat pada hakikat dan keberadaan manusia sebagai makhluk Tuhan Yang Maha Esa dan merupakan anugerah-Nya yang wajib dihormati, dijunjung tinggi dan dilindungi oleh negara, hukum dan Pemerintah, dan setiap orang demi kehormatan serta perlindungan harkat dan martabat manusia.

Pasal 4 UU HAM lebih jelas menyebutkan, bahwa manusia itu punya hak untuk hidup, hak untuk tidak disiksa, hak kebebasan pribadi, pikiran dan hati nurani, hak beragama, hak untuk tidak diperbudak, hak untuk diakui sebagai pribadi dan persamaan di hadapan hukum, dan hak untuk tidak dituntut atas dasar hukum yang berlaku surut adalah hak hak manusia yang tidak dapat dikurangi dalam keadaan keadaan apapun dan oleh siapapun.
Kalau hak itu diabaikan oleh negara melalui birokrat-birokratnya, maka perbuatan demikian ini layak digolongkan sebagai bentuk pelanggaran terhadap hak asasi manusia. Baik ada kesengajaan maupun karena faktor kelalaian, birokrat dapat diperlakukan sebagai pelanggar HAM yang serius bilamana kasus yang ditimbulkannya mengakibatkan problem serius pula.

Pasal 1 angka (6) UU Nomor 39 tahun 1999 menyebutkan, bahwa pelanggaran hak asasi manusia adalah setiap perbuatan seseorang atau kelompok orang termasuk aparat negara baik disengaja maupun tidak sengaja, atau kelalaian yang secara melawan hukum mengurangi, menghalangi, membatasi, dan atau mencabut hak asasi manusia seseorang atau kelompok orang yang dijamin oleh Undang-undang ini, dan tidak mendapatkan, atau dikhawatirkan tidak akan memperoleh penyelesaian hukum yang adil dan benar, berdasarkan mekanisme hukum yang berlaku.

Dalam Pasal 9 Undang-undang Nomor 39 Tahun 1999 tentang Hak Asasi manusia disebutkan, bahwa setiap orang berhak untuk hidup, mempertahankan hidup dan meningkatkan taraf kehidupannya (ayat 1). Setiap orang berhak hidup tenteram, aman, damai, bahagia, sejahtera lahir dan batin (ayat 2), dan setiap orang berhak atas lingkungan hidup yang baik dan sehat (ayat 3).

\footnotetext{
${ }^{18}$ Sidik, Ahmad. Op.Cit, Hlm. 13-14.
} 
Penyesatan lewat informasi yang mengakibatkan fatalisme sosial berupa pelanggaran HAM adalah kebersamaan antara informasi yang keluar dengan tindakan main hakim sendiri (eigenrichting). Begitu ada orang menyebarkan informasi, yang ternyata informasi ini salah, sementara di seputaran komunitas itu terjadi kriminalitas semacam penjarahan harta kekayaan korban bencana alam, maka secara spontan korban menghakimi penyampai informasi sesat ini atau siapapun yang tertangkap basah (haterdaad) sebagai akar masalahnya atau dianggap sedang menjalankan trik penyesatan masyarakat.

Sean Bride, pemenang hadiah nobel perdamaian ini pernah ditanya wartawan tentang hak mendasar yang dimiliki manusia, lantas ia menjawab "hak untuk mendapatkan informasi" (right for information). Mengapa pemenang Nobel ini menjadikan hak mendapatkan informasi sebagai opsinya? Bukankah masih banyak hak-hak asasi manusia lainnya, seperti hak berekspresi, hak berorganisasi, hak berpolitik, hak menentukan pilihan dengan bebas, hak bebas dari ketakutan, dan lainnya? ${ }^{19}$

Rupanya, pemenang Nobel itu benar-benar bisa menangkap dan menerjemahkan urgensinya hak mendapatkan informasi bagi kehidupan dan keberlanjutan hidup manusia. Tanpa informasi yang memadai, barangkali hak-hak manusia lainnya tidak akan banyak gunanya atau gagal ditegakkan dengan baik, benar, dan bertanggungjawab.

Barangkali, saat ini masyarakat sedang dihadapkan dengan kebingungan, kegamangan, dan kondisi serba ketakutan akibat bertubi-tubi bangsa ini diuji dengan berbagai bentuk bencana alam, mulai dari banjir bandang, tanah longsor, semburan lumpur bercampur gas, gunung meletus, hingga tsunami. Berbagai bentuk bencana alam ini membuat masyarakat berpsikologis limbung, berpikiran kurang jernih dan emosinya gampang terusik.

Ketika ada pakar di bidang bencana alam atau ahli deteksi pergerakan bumi menyebutkan temuannya, bahwa pasca tsunami di Aceh, kondisi laut Jawa bagian selatan (seperti Malang selatan), akan menjadi daerah yang rawan tsunami, tidak sedikit anggota masyarakat yang meragukannya dan bahkan menilai kalau informasi yang disampaikan pakar ini hanya membuat masyarakat pesimis dalam menyikapi kehidupan di dunia ini.

Logis jika masyarakat kurang mempercayai informasi semacam itu, karena masyarakat sudah sedemikian sering dihadapkan dengan informasi-informasi yang menyesatkan, membohongi, dan merugikannya. Sudah banyak informasi sampah (garbage information), yang diterima

\footnotetext{
19 Kabul, Imam dkk, (2007). Hukum Informasi Kontemporer, Jakarta: Nirmana Media, Hlm. iii.
} 
dan mendatangkan petaka lain. Informasi menyesatkan ini mengindikasikan kelemahan birokrasi, yang tidak tanggap terhadap problem komplikatif bencana. Kalau birokrasinya lemah, tentulah yang harus dipersalahkan (dituntut) pertanggungjawaban utamanya adalah sosok pimpinan daerah.

Seseorang atau sekelompok orang yang menyebarkan informasi demikian itu layak dikategorikan sebagai pelanggar hak asasi manusia. Misalnya, masyarakat diberi informasi yang bersifat mendadak seperti ada tsunami susulan, atau longsor meluas adalah suatu informasi berbobot tekanan psikologis berkategori serius, yang mengakibatkan masyarakat kalang kabut, kacau, kalut, dan melakukan pergerakan yang tidak terarah dan membabi-buta.

Relawan yang sempat menanyakan mengenai banyaknya korban gempa di Yogya memperoleh testimoni yang mengejutkan, bahwa tidak sedikit korban meninggal disebabkan adanya informasi mendadak atau susulan di tengah kekacauan, yang menyebut "akan ada tsunami" atau "diikuti tsunami", yang mengakibatkan antar anggota masyarakat berlarian berusaha menyelamatkan diri, saling benturan, tabrakan, dan terinjak-injak.

Kasus tsunami yang pernah terjadi di Pangadaraan juga terdapat kesamaan di beberapa hal dengan Yogya. Di saat korban dalam kondisi prihatin (mengenaskan). mencuat informasi susulan atau mendadak yang menyebutkan akan "ada tsunami yang lebih besar". Informasi semacam itu kemudian mengakibatkan masyarakat berlarian tunggang-langgang atau dihadapkan pada kepanikan mencari selamat atau perlindungan. Sikap dan perilaku masyarakat demikian tidak bisa disalahkan, sebab adalah wajar jika mereka berusaha memperjuangkan atau melindungi hak hidup (right for life) dan keberlanjutan hidupnya di tengah masyarakat.

\section{KESIMPULAN}

Realitas memprihatinkan sedang atau sering menimpa masyarakat, yakni bencana alam. Bencana alam di Indonesia ini bukan hanya menimbulkan satu problem, tetapi sudah mengakibatkan banyak problem. Beberapa kesulitan yang diderita korban masih juga diikuti dengan sejumlah dan beragam kesulitan lainnya akibat tindakan birokrat dan manusia-manusia yang menjadi faktor penyebab maupun pelaku pelanggaran hukum dan hak asasi manusia (HAM). Birokrat yang diberi kepercayaan menangani bencana alam merupakan wakil pemerintah yang langsung maupun tidak, telah beberapa kali melakukan pelanggaran hukum dan HAM. Salah satu jenis pelanggarannya adalah tidak ditegakkanya hak atas informasi kepada masyarakat atau korban. 


\section{DAFTAR PUSTAKA}

\section{Peraturan Perundang undangan}

Undang-undang Nomor 39 Tahun 1999 tentang Hak Asasi Manusia

Deklarasi Universal Hak Asasi Manusia (Universal Declaration of Human Right)

\section{Buku}

Sidik, Ahmad. (2009). Negeri Bencana (Refleksi Perjalanan Musibah). Jakarta: Gerbang Pustaka.

Hariyono, Didik. (2015). Birokrasi Bencana di Indonesia. Jakarta: Xpress Indonessia.

Kabul, Imam, dkk. (2007). Hukum Informasi Kontemporer, Jakarta: Nirmana Media.

Suharmanto. (2016). Membedah Akar Bencana. Surabaya: Fajar Ilmu.

Walid, Waliduddin. (2014). Peta Bencana di Indonesia dari Waktu ke Waktu, Jakarta: Aliansi Media.

\section{Makalah}

Toha, Abdillah. Pilkada Berbasis Kemasyarakatan. Makalah disampaikan dalam diskusi di Lembaga Kajian Ilmu Pengetahuan, Teknologi, dan Islam (LPITI) yang bekerjasama dengan Pusat Kajian HAM Fakultas Hukum Unisma Malang, tanggal 15 Agustus 2009.

\section{Internet}

Suara Pembaharuan, 30 Mei 2006, diakses 1 Mei 2017.

Michico, Nathania Riris, (2017, Februari 28), BNPB: 654 Bencana di Awal Tahun 2017, Potensi Banjir Meningkat. Diakses pada Mei 1, 2017. Dari Detik News: https://news.detik.com/berita/d3433672/bnpb-654-bencana-di-awaltahun-2017-potensi-banjir-meningkat.

Muftisany, Hafidz. (2012, Oktober 10), Belajar Manajemen Penanganan Bencana dari Jepang. Diakses Mei 1, 2017. Dari News: http://nasional.republika.co.id/berita/nasional /umum/12/10/10/mbnmqa-belajarmanajemen-penanganan-bencana-dari-jepang 